\title{
Improving Student Performance in an Undergraduate Business Statistics Course Using Technology Enhanced Learning
}

\author{
${ }^{1}$ Harvi H. Millar, ${ }^{2}$ Suzana N. Russell \\ ${ }^{1}$ Saint Mary's University, ${ }^{2}$ University of the West Indies \\ ${ }^{1}$ Canada, ${ }^{2}$ Jamaica
}

\begin{abstract}
After witnessing a steady decline and increased variability in students' performance in Business Statistics over several years, it was clear there was need for a change in how students were engaged in the course. In this case study, we examine the use of a mix of technologies that were introduced in an attempt to improve student engagement and students' performance in terms of average course mark, grade performance, and failure rate. Learning technologies utilized over time include Facebook groups to create a learning common, live streaming tutorial over YouTube, flipping the classroom, polling software, electronic bulletin boards and interactive learning platforms such as Cengage MindTap. Our findings seem to suggest that the use of technology enhanced learning tools resulted in an improvement in mean course mark, grade performance and failure rate when compared to periods when the teaching method was purely didactic and used the traditional lecturebased methodology.
\end{abstract}

\section{Introduction}

Business statistics is a second year required course in the Bachelor of Commerce program at a Canadian university where one of the authors is currently employed. Business statistics is required for all students pursuing a major in Business. This translates into roughly 5 to 7 sections of between 50 to 75 students per section per semester. After witnessing a steady decline and increased variability in students' final course mark in business statistics over several years, it became clear there was need for a change in how students were engaged in the course. It was our view that the current level of student engagement in statistics outside of the classroom was insufficient to yield the desired student performance. Like other statistics instructors, we believed that technology enhanced learning (TEL) may prove to be an effective alternative to the traditional classroom instruction as a means of enhancing students' engagement and performance.

Technology enhanced learning can be defined as the use of learning technology to make learning more effective [1]. Technology has long been recognized as a way of enriching college students' learning experiences and enhancing their academic performance [2]. According to [3] it is hard to imagine teaching statistics today without using some form of technology. Technology can be used to foster deep understanding of statistical principles by providing students with visual and dynamic presentation of ideas, by creating multiple and varied representations of new concepts and by making it possible for students to investigate principles underlying important methodologies [4].

Several studies have explored the use of technological tools in the teaching of statistics and its impact on students' performance. The results from such studies are mixed. For example, [5] found that students who participated in a flipped-hybrid environment viewing lecture material online prior to once a week, face-to-face meetings, performed better on the common final exam, albeit no significant differences in their final grades or student satisfaction. On the other hand, [6] found that students in the traditional classroom lecturing performed slightly better than those who did the course in the computer lab, primarily due to the distractions in the lab like emailing and social networking.

Several technological tools are currently in use in statistics education as highlighted by [3]. Video tutorials are one TEL tool that has been used in the teaching of statistics as a means of improving students' academic performance. For example, [2] used online video tutorials as just-in-time support to enhance students' performance in business statistics, as opposed to traditional classroom instruction. Their results suggest that while the learning benefits of the video tutorials were instrumental to some students, they were less so with other students suggesting that learning technologies benefit students differently. Flipped classroom is also gaining increasing popularity across disciplines. A flipped classroom is a type of active learning where transmission of content occurs outside the classroom environment and problem solving and learning activities become the focus of classroom time [7]. Studies such as [8] have examined the effects of flipped classroom on students' grades when compared to the traditional lecture structure in college algebra. Applets are another TEL tool used in the delivery of statistics. These applets tend to be interactive whereby students 
can manipulate some features or statistical parameters and get to view the resulting outcomes. These applications provide powerful illustrations and have shown to help students with conceptually difficult topics in statistics. For example, [9] used applets to aid in the understanding of sampling variability while [4] taught hypothesis testing using two applets. Audience response systems (also known as clickers and polling systems) are used as a partial solution to the challenge of student engagement [10]. Polling software such as Poll Everywhere and Socrative provide almost instantaneous feedback to instructors which can help them to readily identify classroom trends and the specific needs of students. Even with the increased adoption of TEL tools in statistics education, [2] point out that there is still a lack of research examining and exploring the effects of technology-enhanced pedagogy on business students' statistical learning performance. This research attempts to help fill that gap by adding to the extant literature on TEL tools used in the teaching of business statistics. The main objective of this case study is to examine the relationships between the mix of TEL tools employed in teaching statistics and students' performance measured by average course mark, average grade and failure rate.

\section{Methodology}

The focus of the study is undergraduate business students at a Canadian university. One of the authors has been teaching the mandatory business statistics course for over 25 years. Prior to 2012, the course was delivered in a traditional classroom setting where the teaching method was purely didactic and employed the traditional lecture-based methods. Our search for new approaches to enhance students' engagement and performance led to exposure to several learning technologies that included: Facebook groups; pre and post video lecture summaries; full video lectures of course topics; flipping the classroom; polling software such as Socrative and Poll Everywhere, online streaming of post-class tutorials and office hours over YouTube, electronic bulletin boards such as Padlet, and interactive learning platforms such as Cengage MindTap - a cloud-based learning technology platform that allows for the creation of a highly customizable learning experience for students. Over the past 6 years, we have spent time experimenting with various combinations of these technologies in the hope of identifying the most effective mix that will positively impact students' learning and engagement in the course. The learning technologies explored and the ways in which they were used to augment the course are summarized in Table 1.

We examine student performance data between 1998 and 2018. For the purpose of analysis, we divide this data into three periods: 1998-2007 when we believe technology on personal devices was not yet ubiquitous; 2008-2011 the period during which the decline of student performance appeared significant; and 2012-2018 which is the period during which the learning technologies were deployed in an effort to address the decline in students' performance. An online version of the course was introduced in 2017 and taught three times.

Table 1. Technologies Explored for Enhancing Engagement with the Course

\begin{tabular}{|l|l|}
\hline Technology & Use in Augmenting the Course \\
\hline Facebook Groups & $\begin{array}{l}\text { Facebook groups (FBGs) allow students to come together to form a peer-learning } \\
\text { community - a learning commons. A closed Facebook group was established for the } \\
\text { course. It facilitated several valuable functions: } \\
-\quad \text { allowing students to post questions and have their peers or the instructors respond } \\
-\quad \text { a place for students to go for help from the entire class and the instructor. } \\
\text { The posting of short (5-minute) pre-and post-video summaries of a current topic } \\
\text { in the course } \\
\text { Lectures/Tutorials }\end{array}$ \\
$\begin{array}{l}\text { posting of solutions to assignments } \\
\text { Videos of lectures were first created as an additional access channel for the lectures } \\
\text { that was previously covered. }\end{array}$ \\
$\begin{array}{l}\text { Eventually the lecture videos were used to facilitate flipping the classroom. } \\
\text { Video tutorials were produced to demonstrate how to solve difficult problems in areas } \\
\text { such as regression and analysis of variance. Students typically commented that despite } \\
\text { taking copious notes in class, the procedural steps for solving a problem were quickly } \\
\text { forgotten after class. }\end{array}$ \\
\hline $\begin{array}{l}\text { Online tutorials and office hours were introduced in recognition of the fact that our } \\
\text { Online Tutorials and } \\
\text { Office Hours } \\
\text { not all students (many of whom worked) could access office hours during the day. Online }\end{array}$ \\
\hline
\end{tabular}




\begin{tabular}{|c|c|}
\hline & $\begin{array}{l}\text { tutorials were offered typically in the evening using YouTube Livestreaming. Since the } \\
\text { sessions were captured by YouTube, it was available to those who could not attend the } \\
\text { online sessions in real time. }\end{array}$ \\
\hline $\begin{array}{l}\text { Recording In-class } \\
\text { Lectures }\end{array}$ & $\begin{array}{l}\text { Recognizing that after the second week of the semester, class attendance typically drops } \\
\text { to between } 50 \%-65 \% \text {. It was felt that lecture capturing could be very useful, not only to } \\
\text { those who missed classes, but also for those students who attended the class and wanted } \\
\text { an opportunity to "re-live" parts of the lecture. The availability of whiteboard apps with } \\
\text { recording functionality made that possible. For example, using an iPad with an app such } \\
\text { as Explain Everything and coupling the iPad to the overhead projector, the lecture could } \\
\text { be delivered in class and recorded simultaneously. }\end{array}$ \\
\hline Flipped Classroom & $\begin{array}{l}\text { Several students indicated that many of the concepts in statistics were difficult to grasp } \\
\text { and that the number of examples worked during a lecture was inadequate. Splitting } 75 \\
\text { mins of class time between introduction of theory and demonstration of the theory simply } \\
\text { did not allow for sophisticated examples to be worked through in class. By moving the } \\
\text { lectures outside of the classroom and using the gained class time for active learning, } \\
\text { students were given the opportunity to better their comprehension of the more difficult } \\
\text { topics with the instructor being available to assist or coach the students needing help. }\end{array}$ \\
\hline $\begin{array}{l}\text { Socrative/Poll } \\
\text { Everywhere }\end{array}$ & $\begin{array}{l}\text { In support of the flipped classroom, it was important to obtain a sense of the level of } \\
\text { comprehension of the core principles covered in the video lectures prior to classes. } \\
\text { Socrative and Poll Everywhere allowed for the development of short 5-10-minute multiple } \\
\text { choice quizzes. The live polling results showed the class how they performed and also } \\
\text { provided the instructor with valuable information on areas in a lecture that required } \\
\text { additional focus to enhance overall comprehension. }\end{array}$ \\
\hline Cengage MindTap & $\begin{array}{l}\text { Cengage MindTap is a power digital learning platform that allows for complete } \\
\text { customization of a course. It can be used to deliver a completely online or a blended } \\
\text { learning version of the course. } \\
\text { MindTap was adopted in } 2015 \text { and used in both capacities. In } 2017 \text {, the business school } \\
\text { introduced an online version of the business statistics course which was delivered using } \\
\text { Cengage MindTap. This TEL tool has also been used between 2015-2018 to support the } \\
\text { flipped class model for face-to-face delivery of the course. }\end{array}$ \\
\hline Zoom Meeting & $\begin{array}{l}\text { Zoom meeting was introduced in the fall of } 2016 \text { as an alternative to YouTube streaming } \\
\text { in order to enhance the quality and effectiveness of online lectures, office hours and } \\
\text { tutorials. It allows for two-way voice communication with audio/video and recording of } \\
\text { the meeting which could be subsequently uploaded to YouTube. Zoom meeting also } \\
\text { allows for private conversations where students can be held in a waiting room and then } \\
\text { brought into the meeting with the instructor one at a time. }\end{array}$ \\
\hline Padlet & $\begin{array}{l}\text { Between } 2012 \text { and } 2017 \text {, we saw a decreasing trend in student interaction with the } \\
\text { Facebook groups. This was reflected by the small number of students who accessed the } \\
\text { group when material was posted (solutions, lectures, etc.) One possible reason for the } \\
\text { decline in use may be as a result of the rise in other social media platforms such as } \\
\text { Snapchat and Instagram between } 2016 \text { and } 2018 \text {. } \\
\text { In retrospect, since the Facebook group was used largely as a bulletin board, we considered } \\
\text { using Padlet as a viable replacement for a number of reasons. Padlet is a well-structured } \\
\text { electronic bulletin board that offer great flexibility in posting and organizing learning } \\
\text { material. It allows for effective peer-support, posting of course content, posting of queries, } \\
\text { and links to websites. Padlet, like Facebook, facilitated the creation of a learning } \\
\text { commons. }\end{array}$ \\
\hline
\end{tabular}

\section{Data analysis and findings}

Between Fall 2012 and Spring 2018, combinations of the above-mentioned learning technologies were introduced in the business statistics course. Table 2 shows the mix of technologies we experimented with and the resulting impact on student engagement and performance. There was no formal experimental design, but rather an attempt to apply learning technologies that did not require support from the institution and that students could access at no extra cost to them. For example, when MindTap was introduced as the digital learning platform, it was introduced through the adoption of a textbook for which the corresponding MindTap platform existed. This section presents the findings with respect to student performance and student engagement for the various combinations of TEL tools used. 
Table 2. Mix of Technologies Deployed Between Fall 2012 - Spring 2018

\begin{tabular}{|c|c|c|c|}
\hline Year & $\begin{array}{l}\text { Learning Technologies } \\
\text { Deployed }\end{array}$ & Students' engagement/feedback & Students' performance \\
\hline $\begin{array}{l}\text { Fall } \\
2012\end{array}$ & $\begin{array}{ll} & \text { Facebook Group } \\
\text { - } & \text { Online office } \\
\text { hours/video } \\
\text { tutorials via } \\
\text { YouTube } \\
\text { livestreaming }\end{array}$ & $\begin{array}{l}\text { Students were very receptive of the } \\
\text { introduction of familiar technology in } \\
\text { learning. In particular, they welcomed the } \\
\text { use of the Facebook group as indicated by } \\
\text { the following statements about post- } \\
\text { lecture video summaries: } \\
\text { "Thank you, Professor, this is really a } \\
\text { great idea, thank you for doing this for } \\
\text { us" } \\
\text { "Great way to reiterate the learning } \\
\text { objectives. By referring to this } \\
\text { presentation, it allows me to remember } \\
\text { the actual lecture, sort of an abstract } \\
\text { account. Thank you. Very well done." }\end{array}$ & $\begin{array}{l}\text { Average students' } \\
\text { performance as measured } \\
\text { by students' grades, } \\
\text { increased by } 8 \% \text { - from } \\
62 \% \text { (2011) to } 70 \% \text {. } \\
\text { Failure rate dropped by } \\
10 \% \text { - from an average of } \\
24 \% \text { (2011) to } 14 \% \text {. }\end{array}$ \\
\hline $\begin{array}{l}\text { Fall } \\
2013\end{array}$ & $\begin{array}{l}\text { 1. Facebook Group } \\
\text { 2. Online office } \\
\text { hours/video } \\
\text { tutorials via } \\
\text { YouTube } \\
\text { livestreaming } \\
\text { Video lectures - } \\
\text { these were not used } \\
\text { to flip the } \\
\text { classroom, but } \\
\text { rather provided } \\
\text { students with the } \\
\text { opportunity to } \\
\text { stream the lecture } \\
\text { on demand. }\end{array}$ & $\begin{array}{l}\text { Several students commented that this was } \\
\text { invaluable as they rarely fully understood } \\
\text { the concepts at the end of the class, } \\
\text { particularly, difficult concepts like } \\
\text { regression and analysis of variance }\end{array}$ & $\begin{array}{l}\text { Average final grade of } \\
70 \% \text {. } \\
\text { - } 30 \% \text { of the students } \\
\text { scored an A- or higher } \\
\text { - } \quad \text { Failure rate - } 16 \% \text {. }\end{array}$ \\
\hline $\begin{array}{l}\text { Fall } \\
2015\end{array}$ & $\begin{array}{ll}\text { - } & \text { Facebook Group } \\
\text { - } & \text { Online office } \\
\text { hours/video } \\
\text { tutorials via } \\
\text { YouTube } \\
\text { livestreaming } \\
\text { - } \quad \text { Video lectures } \\
\text { - } \quad \text { MindTap - used for } \\
\text { blended learning } \\
\text { - } \quad \text { Flipped classroom } \\
\text { - } & \text { Socrative - } \\
\text { iPad with Explain } \\
\text { Everything } \\
\text { whiteboard app }\end{array}$ & $\begin{array}{l}\text { MindTap was introduced to strengthen the } \\
\text { use of blended learning. Students } \\
\text { appreciated the opportunity to self-test } \\
\text { and obtain immediate feedback. } \\
\text { The flipped classroom was a novel idea to } \\
\text { the students. Many embraced the concept. } \\
\text { Others were not too happy about having } \\
\text { to watch the lectures prior to attending } \\
\text { classes particularly when the practice is } \\
\text { not being reinforced by other classes } \\
\text { taken by the students. } \\
\text { The use of Socrative and live polling was } \\
\text { viewed as exciting. The immediate } \\
\text { feedback on how well particular concepts } \\
\text { were understood and the opportunity for } \\
\text { address the gaps in understanding was } \\
\text { strongly appreciated. } \\
\text { Finally, the recording of the worked } \\
\text { problems in class using a whiteboard app } \\
\text { with recording functionality was regarded }\end{array}$ & $\begin{array}{l}\text { - Average final grades for } 2 \\
\text { sections of the course - } \\
75 \% \text { and } 74 \% \text {. } \\
32 \% \text { and } 33 \% \text { of the } \\
\text { students received an A- or } \\
\text { higher } \\
\text { Failure rates - } 15 \% \text { and } \\
10 \% \text {. }\end{array}$ \\
\hline
\end{tabular}




\begin{tabular}{|c|c|c|c|}
\hline & & $\begin{array}{l}\text { as extremely beneficial. Students were } \\
\text { able to watch how the problem was } \\
\text { solved many times over. }\end{array}$ & \\
\hline $\begin{array}{c}\text { Fall } \\
2016\end{array}$ & $\begin{array}{ll}\text { - } & \text { Facebook Group } \\
\text { - } & \text { Online office hours } \\
\text { - } & \text { Video tutorials - } \\
& \text { now using Zoom } \\
\text { - } & \text { } \text { Videeting lectures } \\
\text { - } & \text { MindTap - used for } \\
\text { - } & \text { blended learning } \\
\text { - } & \text { Socrative classroom } \\
\text { - } & \text { iPad with Explain } \\
& \text { Everything } \\
\text { whiteboard app }\end{array}$ & $\begin{array}{l}\text { The mix of technologies remained } \\
\text { unchanged in } 2016 \text {. Student feedback } \\
\text { was similar to that received in } 2015 \text {. } \\
\text { We did notice that for one of two sections } \\
\text { of the course, classroom attendance was } \\
\text { extremely low - about } 25 \% \text { in contrast } \\
\text { with an average of } 70 \% \text { attendance for the } \\
\text { other section. The sentiment was } \\
\text { expressed that the availability of the } \\
\text { YouTube video lectures as well as the } \\
\text { recorded classroom problems meant that } \\
\text { several students felt they could afford to } \\
\text { miss classes. } \\
\text { Unsurprisingly, the results for the two } \\
\text { sections were very different. }\end{array}$ & 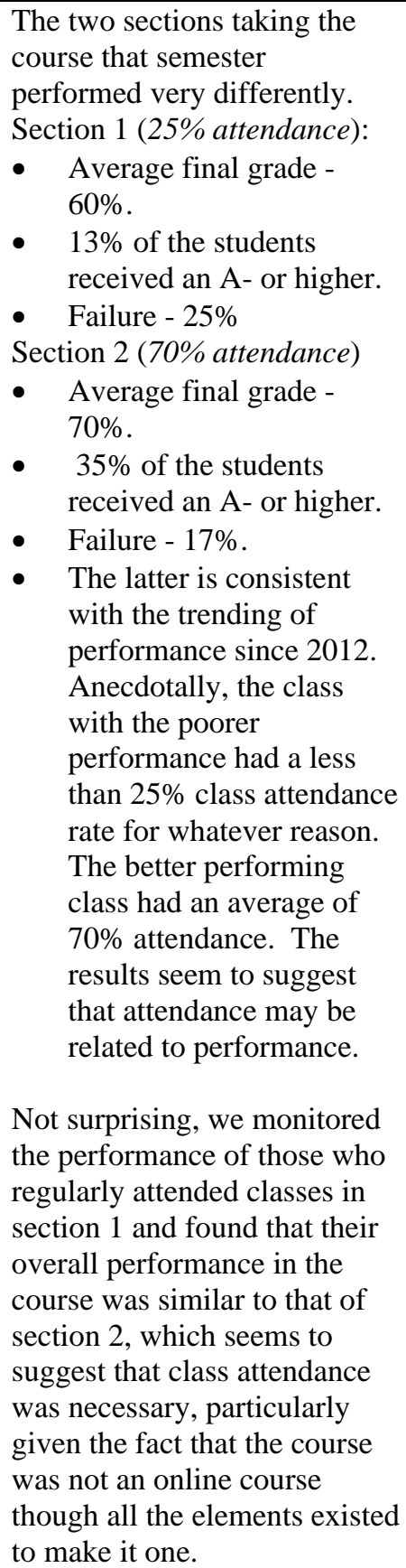 \\
\hline $\begin{array}{l}\text { Winter } \\
2017 \\
\text { Taught } \\
\text { Online }\end{array}$ & $\begin{array}{ll}\text { - } & \text { Online office hours } \\
\text { - } & \text { Video tutorials } \\
\text { - } & \text { YouTube: Video } \\
& \text { lectures } \\
\text { - } & \text { MindTap - Online } \\
& \text { learning } \\
\text { - } & \text { Blended Learning } \\
\text { - } & \text { Zoom meetings }\end{array}$ & $\begin{array}{l}\text { The class was not flipped as it was } \\
\text { facilitated purely online. } \\
\text { Regular online meetings were scheduled, } \\
\text { but students felt that the availability of the } \\
\text { video lectures, and the MindTap resources } \\
\text { meant that it was not necessary to attend } \\
\text { classes. } \\
\text { - MindTap captured student use of the } \\
\text { platform which showed: }\end{array}$ & $\begin{array}{ll}\text { - } & \text { No of students enrolled = } \\
& 26 \\
\text { - } & \text { Average grade }-64 \% \\
\text { - } & 5 \% \text { obtained an A- or } \\
& \text { higher in the course. } \\
\text { - } & \text { Failure rate }-0 \%\end{array}$ \\
\hline
\end{tabular}




\begin{tabular}{|c|c|c|c|}
\hline & & $\begin{array}{l}\text { - Average hours students spent logged } \\
\text { in the course - } 23 \mathrm{hr} \\
\text { No of times logged in over the } \\
\text { semester - } 35 \text { times } \\
\text { - Assigned supplemental activities } \\
\text { attempted - } 23 \%\end{array}$ & \\
\hline $\begin{array}{l}\text { Winter } \\
2018 \\
\text { Taught } \\
\text { Online }\end{array}$ & $\begin{array}{ll}\text { - } & \text { Online office hours } \\
\text { - } & \text { Video tutorials } \\
\text { - } & \text { YouTube: Video } \\
& \text { lectures } \\
\text { - } & \text { MindTap - Online } \\
& \text { learning } \\
\text { - } & \text { Blended learning } \\
\text { - } & \text { Zoom meetings } \\
\end{array}$ & $\begin{array}{l}\text { Student engagement show: } \\
\text { - Average hours students spent logged } \\
\text { in the course - } 68 \mathrm{hrs} \\
\text { - } \quad \text { No of times logged in over the } \\
\text { semester - } 61 \text { times } \\
\text { - Assigned supplemental activities } \\
\text { attempted - } 20 \%\end{array}$ & $\begin{array}{ll} & \text { No of students enrolled }= \\
& 49 \\
\text { - } & \text { Average grade }-80 \% \\
\text { - } & 65 \% \text { obtained an A- or } \\
& \text { higher in the course. } \\
\text { - } & \text { Failure rate }-9 \%\end{array}$ \\
\hline $\begin{array}{l}\text { Fall } \\
2018 \\
\text { Taught } \\
\text { Online }\end{array}$ & $\begin{array}{ll}\text { - } & \text { Online office hours } \\
\text { - } & \text { Video tutorials } \\
\text { - } & \text { YouTube: Video } \\
& \text { lectures } \\
\text { - } & \text { MindTap - Online } \\
& \text { learning } \\
\text { - } & \text { Blended Learning } \\
\text { - } & \text { Zoom meetings }\end{array}$ & $\begin{array}{l}\text { Student engagement for this course } \\
\text { shows: } \\
\text { - Average hours students spent logged } \\
\text { in the course - } 68 \text { hrs } \\
\text { - No of times logged in over the } \\
\text { semester - } 30 \text { times } \\
\text { - Assigned supplemental activities } \\
\text { attempted - } 7 \%\end{array}$ & 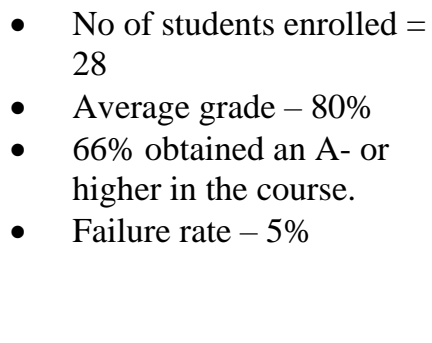 \\
\hline
\end{tabular}

85

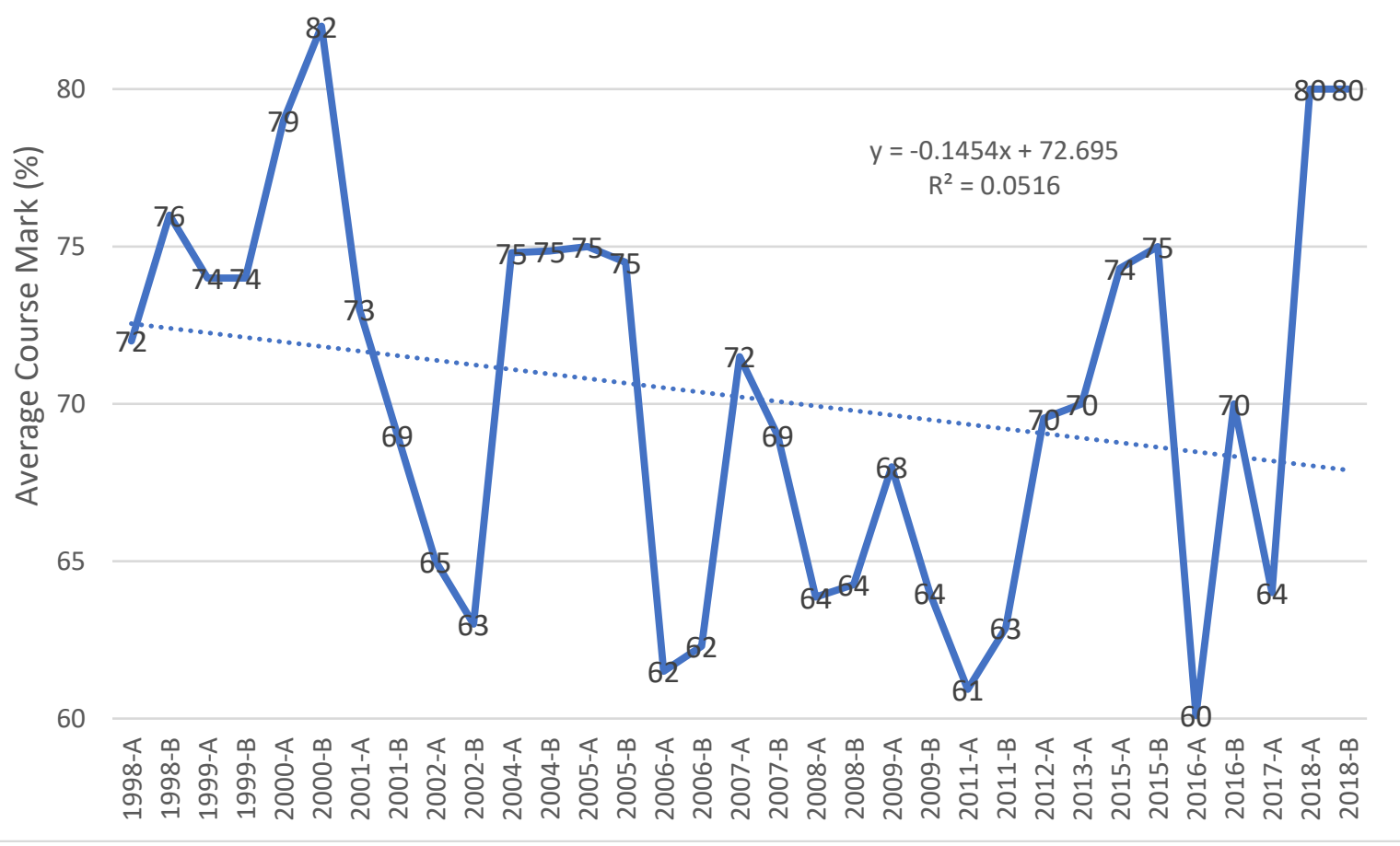

Figure 1. Average Final Course Mark Performance between 1998-2018

* For all the figures A and B indicate separate sections of the course 


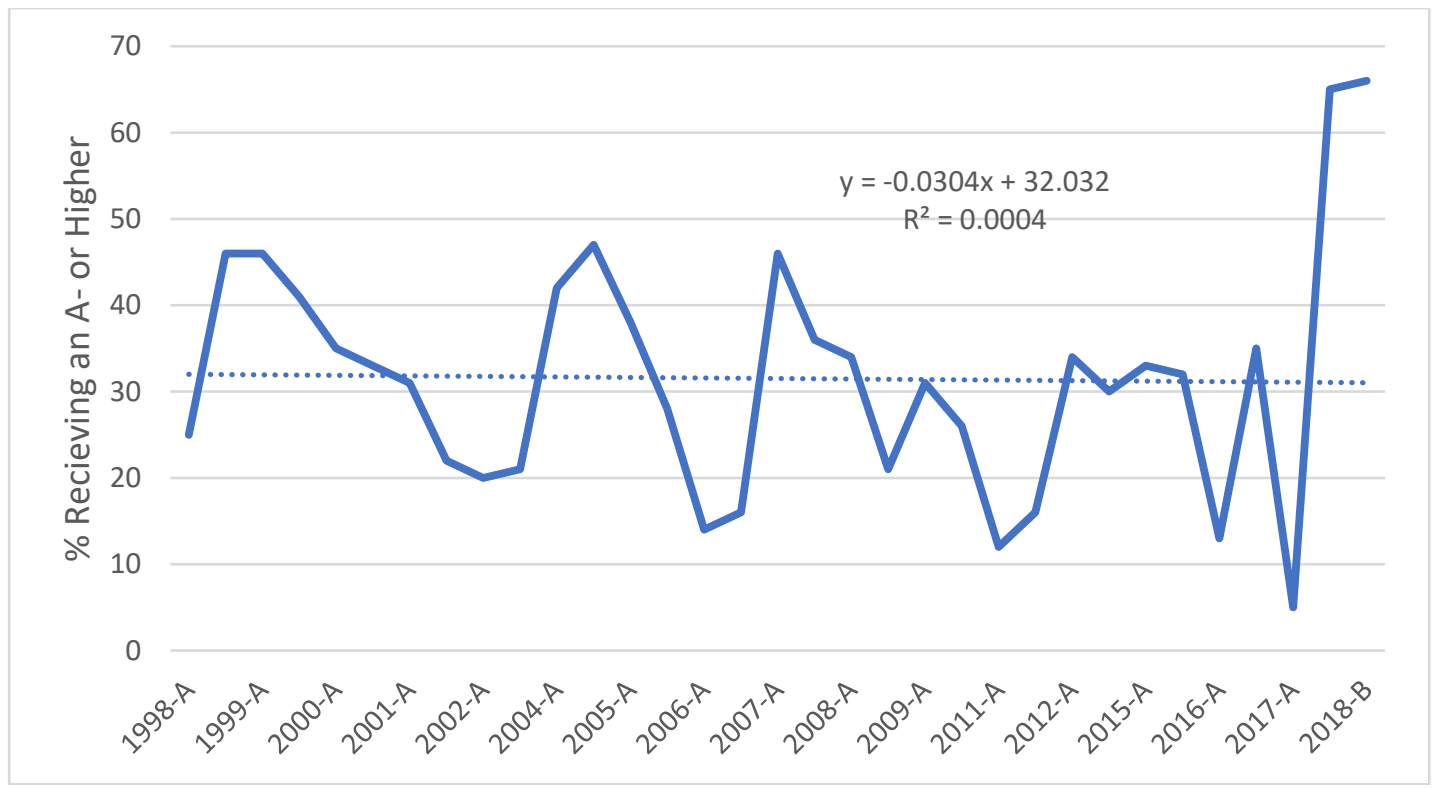

Figure 2. Percentage of Students Getting A- or Higher Between 1998-2018

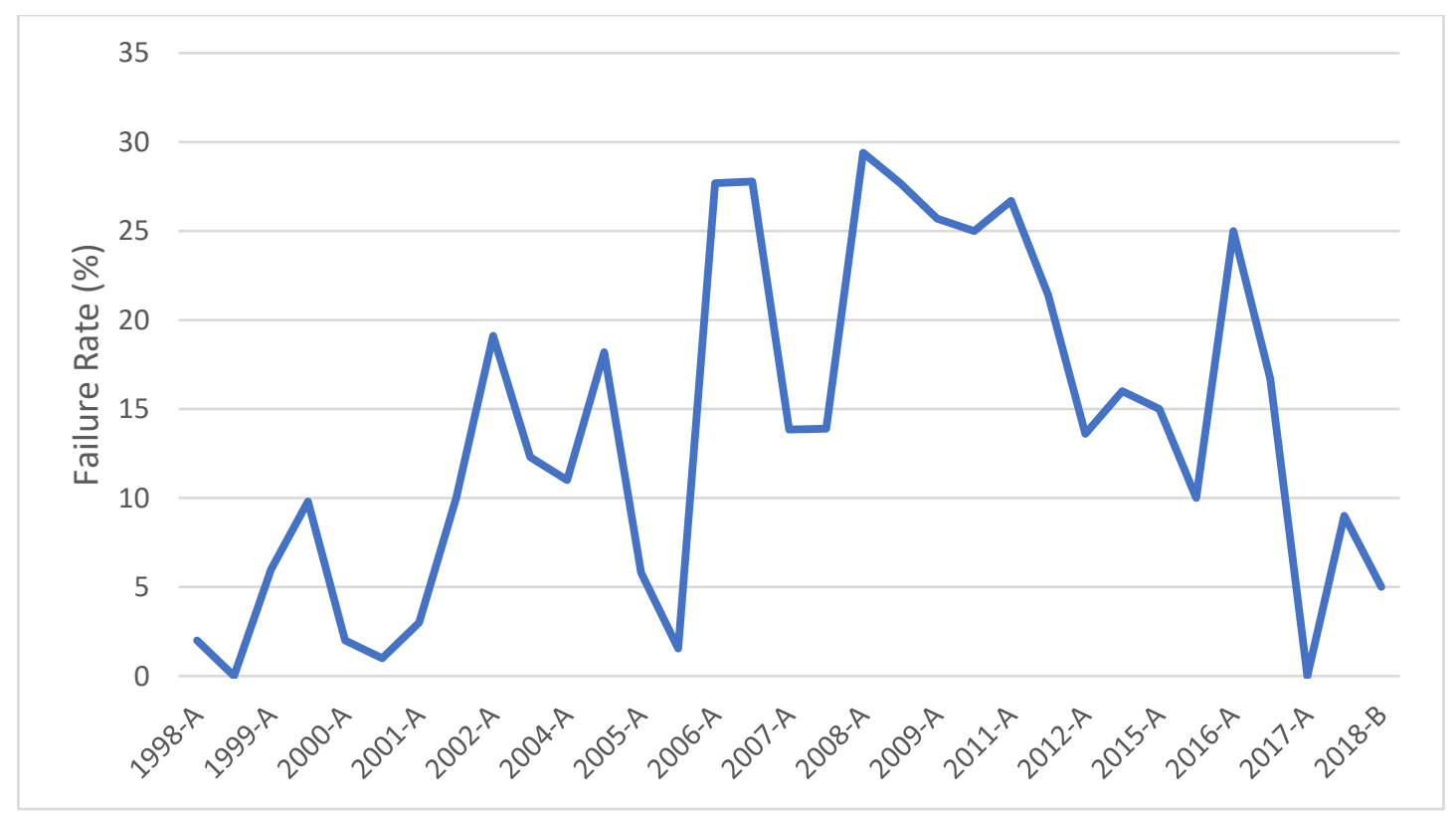

Figure 3. Failure Rate (\%) between 1998-2018

\section{Observations on Student Performance between 1998-2018}

In this section we examine the differences between student performance over the three periods: 19982007 which we view as a period in which social media on personal devices was not yet ubiquitous and as such we term this period 'low social media'; 2008-2011 which we term 'high social media' because there was a growing proliferation of cell phones and fervent use of social media technology such as MSN messenger, Black Berry Messenger, My Space, and Facebook; and 2012-2018 when we ventured into the realm of TEL.
Students' performance in terms of final course mark, percentage of students getting an A- or higher, and failure rate over the period $1998-2018$ are shown in Figures 1-3. The results show a fair degree of variability in the 3 measures over the 20-year period.

We summarize the differences in students' performance over the three periods: low social media, high social media and TEL, in addition to the 20-year period. The results are shown in Table 3. The period between 2008 and 2011 shows a decline in performance with an average course mark of $64 \%$, only $23 \%$ of students receiving an A- or higher, and a failure rate of $26 \%$. This period of decline was the main motivating factor for us experimenting with TEL 
tools. The results seem to indicate that TEL played a significant role in helping to restore student performance to that of the 'low social media' period. The goal of restoring students' performance was achieved, and the failure rate fell to $12.3 \%$, which is a $14 \%$ reduction when compared to the 'high social media' period.

Table 3. Summary of Student Performance

\begin{tabular}{|l|c|c|c|}
\hline Period & Final Course Mark (\%) & $\begin{array}{c}\text { A- or Higher } \\
(\boldsymbol{\%})\end{array}$ & Failure Rate (\%) \\
\hline $\mathbf{1 9 9 8 - 2 0 1 8}$ & 70.2 & 31.5 & 13.7 \\
\hline $\begin{array}{l}\text { Low social media } \\
(\mathbf{1 9 9 8 - 2 0 0 7 )}\end{array}$ & 69.8 & 30.3 & 14.2 \\
\hline $\begin{array}{l}\text { High social media } \\
(\mathbf{2 0 0 8 - 2 0 1 1 )}\end{array}$ & $\mathbf{6 4 . 0}$ & $\mathbf{2 3 . 3}$ & $\mathbf{2 6}$ \\
\hline TEL (2012-2018) & 71.4 & 34.8 & 12.3 \\
\hline
\end{tabular}

We conducted an ANOVA on students' performance over the 3 periods to determine if the differences were statistically significant. The results, which are summarized in Table 4, reveal significant differences in average course mark and failure rate, with the differences attributed to the 2008-2011 period. There are no significant differences in the percentage of students getting an A- or higher. However, a one- tailed t-test comparing the periods 1998-2007 and 2008-2011 show evidence that the percentage of students getting an A- or higher is greater for the period 1998-2007 $(\mathrm{p}=0.1)$. A similar one-tailed t-test for 2008-2011 and 2012-2018 did not yield a significant result. This is likely due to the smaller sample sizes and the level of variability in the data.

Table 4. Summary of ANOVA Results

\begin{tabular}{|l|c|c|c|}
\hline & \multicolumn{2}{|c|}{ ANOVA Results for the Difference Between Means } \\
\hline & Average Course Mark & A - or Higher & Failure Rate \\
\hline F-statistic & 4.54 & 1.36 & 9.789 \\
\hline$p$-value & $0.0188^{*}$ & 0.271 & $0.00053^{* *}$ \\
\hline
\end{tabular}

* Significant at a $5 \%$ level

** Significant at a $1 \%$ level

Table 5 summarizes the strength and direction of a linear trend for the three periods. We report the value of the coefficient of determination $\left(\mathrm{r}^{2}\right)$ and the direction of the trend. The results show that the trend is significant in some cases. For the period 1998-2007 it appears that failure rate was trending upwards towards the latter part of the period. For the 20082011 period all results were trending downwards including the failure rate. Our data shows that the highest failure rates for that period occurred at the beginning, $29 \%$ compared to $21 \%$ at the end. For 2012-2018, we observe average marks and the percentage of students getting an A- or higher trending upwards while the failure rate trended downwards. The results show once again that the period 2012-2018 was a period of recovery with respect to students' performance.

Table 5. $\mathrm{R}^{2}$ Values for a Linear Trend for Performance in the Three Periods

\begin{tabular}{|l|c|c|c|}
\hline Period & Average Course Marks & A - or Higher & Failure Rate \\
\hline $\begin{array}{l}\text { Low social media } \\
(1998-2007)\end{array}$ & $\begin{array}{c}0.2075 \\
\text { (negative trend) }\end{array}$ & $\begin{array}{c}0.0375 \\
\text { (negative trend) }\end{array}$ & $\begin{array}{c}0.397 \\
\text { (positive trend) }\end{array}$ \\
\hline $\begin{array}{l}\text { High social media } \\
(2008-2011)\end{array}$ & $\begin{array}{c}0.191 \\
\text { (negative trend) }\end{array}$ & $\begin{array}{c}0.579 \\
\text { (negative trend) }\end{array}$ & $\begin{array}{c}0.733 \\
\text { (negative trend) }\end{array}$ \\
\hline TEL (2012-2018) & $\begin{array}{c}0.099 \\
\text { (positive trend) }\end{array}$ & $\begin{array}{c}0.165 \\
\text { (positive trend) }\end{array}$ & $\begin{array}{c}0.316 \\
\text { (negative trend) }\end{array}$ \\
\hline
\end{tabular}




\section{Conclusion}

Statistics is generally regarded as a difficult course by many business students. It is not uncommon to witness failure rates of up to $30 \%$. It has been a constant goal of ours to keep the failure rate in the course to below 15\%. Between 1998 and 2007, the failure rate in the course averaged $14.6 \%$. The rising failure rate to $26 \%$ between 2008 and 2011 suggested some level of misalignment between how students were learning and the way in which the course was being taught and that there was a need for correction. The need to address the growing failure rate led to our foray into technology enhanced learning. A mix of technology-based learning support tools were deployed between 2012 and 2018 as the authors became more and more familiar with different learning technologies and their capabilities.

Student performance over the period 2012-2018 showed a marked improvement in the average overall course mark, the percentage of students finishing the course with an A-grade or higher, and course failure rate. The average failure rate has fallen to $12.3 \%$ from a high of $26 \%$ and many students have indicated that the Facebook group, video lectures, and video tutorials played a significant role in enhancing their performance in the course. Some indicated that while they noted the potential value of the flipped method, as the semester wore on with multiple assignments from other courses taken concurrently, it became difficult to maintain the level of preparedness needed to ensure a fruitful experience in a flipped class. Online tutorials and office hours provided great flexibility for those who were unable to attend face to face office hours. However, given that the online sessions were recorded, approximately only $20 \%$ of the class showed up online. Students accessed the recorded session on YouTube after it was posted.

In summary, we are of the view that three key success factors are at the heart of our experience with TEL: 1) the flexibility in the choice to engage with different learning support tools (YouTube videos, online meetings, Facebook groups, etc.); 2) asynchronous learning - allowing students to learn at their own pace (MindTap, YouTube lecture videos, recorded tutorials), and 3 ) the availability of a virtual learning commons (Facebook groups, Padlet) where students can meet and provide peer support. While we have yet to fully entrench Padlet, we believe that using Padlet as an aggregation point for student engagement within the course will allow for all three success factors to co-exist while minimizing the distraction that going to Facebook brings. It is our intent therefore to make full use of Padlet going forward.

\section{Suggestions for Future Research}

In any one semester between 5 and 7 sections of business statistics are usually taught. While the course curriculum is the same in all sections, instructors choose their own teaching methodology. We are not aware of the use of TEL in any of the sections taught by other instructors. While we believe that the average course marks may not be strongly dissimilar, we do believe the greatest impact is in reducing the overall course failure rate and increasing student engagement. For future research we will analyze the relationship between failure rate and the use of TEL in all sections of undergraduate business statistics at the university.

\section{Acknowledgements}

We would like to acknowledge the generous support of Dean Patricia Bradshaw who provided the funding to purchase various pieces of equipment used in facilitating our experimentation with TEL.

\section{References}

[1] A. Thanaraj, and S. Williams, "Supporting the adoption of technology enhanced learning by academics at universities", Journal of Teaching and Learning with Technology, 5(1), 59-86, (2016).

[2] G. Lai, Z. Zhu, and D. Williams, "Enhance students' learning in business statistics class using video tutorials", Journal of Teaching and Learning with Technology, 6 (1), 31-44, (2017).

[3] B. Chance, D. Ben-Zvi, J.B. Garfield, and E. Medina, "The role of technology in improving students learning in statistics",

Technology Innovations in Statistics Education, 1., (2007), Retrieved from https://escholarship.org/uc/item/8sd2t4rr.

[4] K. Schneiter, "Two applets for teaching hypothesis testing", Journal of Statistics Education, 16 (3), (2008). https://doi.org/10.1080/10691898.2008.11889575.

[5] J. Haughton, and A. Kelly, A., "Student performance in an introductory business statistics course: does delivery mode matter?" Journal of Education for Business, 90 (1), 31- 43, (2015).

[6] L.R. Martin, "Teaching business statistics in a computer lab: benefit or distraction?" Journal of Education for Business, 86 (6), 326-331, (2011).

[7] E. Cilli-Turner, "Measuring learning outcomes and attitudes in a flipped introductory statistics course", Problems, Resources

and Issues in Mathematics Undergraduate Studies, 2 (910), 833-846, (2015).

[8] J. Overmyer, "Research on flipping college algebra: lessons learned and practical advice for flipping multiple 
sections", Problems, Resources and Issues in Mathematics Undergraduate Studies, 25 (9-10), 792-802, (2015).

[9] S. N. McDaniel, and L.B. Green, "Using applets and video instruction to foster students' understanding of sampling variability", Technology Innovations on Statistics Education, 6 (1), (2012). Retrieved from https://escholarship.org/uc/item/1nh4n607.

[10] P. McGivern, and M. Coxon, "Student polling software: where cognitive psychology meets educational practice", Frontiers in Psychology, 6, 55, (2015). Retrieved from https://doi.org/10.3389/fpsyg.2015.00055. 